\title{
EFFECTIVENESS OF PRESTRESSED NSM CFRP LAMINATES FOR THE FLEXURAL STRENGTHENING OF RC SLABS
}

\author{
M. R. Mostakhdemin Hosseini ${ }^{1}$, S. J. E. Dias ${ }^{2}$ and J. A. O. Barros ${ }^{3}$ \\ ${ }^{1}$ Phd Student, ISISE, Dep. of Civil Eng., Univ. of Minho, Azurém, 4810-058 Guimarães, Portugal, hoseini_engineer@yahoo.com \\ 2 Assistant Prof., ISISE, Dep. of Civil Eng., Univ. of Minho, Azurém, 4810-058 Guimarães, Portugal, sdias@ civil.uminho.pt \\ ${ }^{3}$ Full Prof., ISISE, Dep. of Civil Eng., Univ. of Minho, Azurém, 4810-058 Guimarães, Portugal, barros@ civil.uminho.pt
}

\begin{abstract}
An experimental program was carried out to investigate the effect of the prestressed Near Surface Mounted (NSM) Carbon Fiber Reinforced Polymer (CFRP) laminates on the behavior of reinforced concrete (RC) slabs. Four RC slabs were tested, a reference slab (without CFRP), and three slabs flexurally strengthened using NSM CFRP laminates with different prestress level of the ultimate tensile strength of the CFRP: $0 \%, 20 \%$ and $40 \%$. The experimental program is described and the main results are presented and analyzed in terms of the structural behavior of the RC slabs, failure modes and performance of the NSM technique with prestressed CFRP laminates. The results show that prestressing CFRP laminates with NSM technique is an effective solution to increase cracking, service, yielding and maximum loads of RC slabs failing in bending. By applying $20 \%$ of prestressed NSM CFRP laminates, the service and ultimate loads have increased, respectively, $55 \%$ and $136 \%$, when the corresponding values of the reference slab are taken for comparison purposes, while $119 \%$ and $152 \%$ were the increase when applying $40 \%$ of prestressed laminates. A numerical strategy was used to evaluate the load-deflection of the tested RC slabs, and a good agreement between experimental and numerical results was obtained.
\end{abstract}

KEYWORDS: CFRP laminates, NSM technique, Flexural strengthening, RC slabs, Experimental results, Numerical simulation

\section{INTRODUCTION}

Carbon fiber reinforced polymer (CFRP) materials have high potential for an effective strengthening of reinforced concrete (RC) structural elements, since they are lightweight, have high durability (non corrodible), exhibit high tensile strength and their availability are practically unlimited in size, geometry and dimensions [1-3]. The possibility of making relative fast interventions without interfering with the normal functionality of the RC structures and minor level of interference that this technique introduces in terms of architectural and aesthetic point-of-views are important advantages of the CFRP-based strengthening solutions. 
Existing studies confirm that among the flexural strengthening techniques of RC elements with passive CFRP materials, Near Surface Mounted (NSM), based on the installation of narrow strips of CFRP laminates, of rectangular cross section, into thin slits open on the concrete cover of the RC elements, is the most effective one [4-6]. The CFRP laminates are bonded to concrete by an epoxy adhesive.

The efficacy of the NSM strengthening technique with passive CFRP laminates to increase the flexural resistance of RC beams [4-9] and slabs [10] was already well assessed. In fact, NSM CFRP laminates without any prestress level can increase significantly the ultimate load carrying capacity of RC structural elements, and high mobilization of the tensile properties of the CFRP can be assured. However, for deflection levels corresponding to the serviceability limit states the benefits of the CFRP is, in general, of small relevance. By prestressing the CFRP, its high tensile capacity is more effectively used, contributing to increase significantly the load carrying capacity of the strengthened elements under both service and ultimate conditions. The prestress can also contribute to close eventual existing cracks, to decrease the tensile stress installed in the existing flexural reinforcement, and to increase the shear capacity of these elements. Thus, prestressing the CFRP seems to be a cost-effective solution to increase both the structural performance and the durability of the strengthened RC structure.

Recent experimental research [11-14] has demonstrated that applying NSM CFRP laminates with a certain prestress level for the flexural strengthening of RC beams can mobilize better the potentialities of these high tensile strength materials, with an appreciable increase of the load carrying capacity at serviceability and ultimate limit states.

In this study, the effectiveness of the NSM technique with prestressed CFRP laminates for the flexural strengthening of RC slabs is assessed. Four RC slabs were executed with the purpose of evaluating the influence of the prestressed level in the behavior of this kind of structures in terms of serviceability and ultimate limit states. A detailed description of the carried out experimental program is provided, and the obtained results are presented and analyzed. To simulate the response of the tested RC slabs in terms of force versus deflection, a numerical strategy based on a cross section layer model and matrix stiffness method was used. The numerical strategy is described and its predictive performance is assessed in this work.

\section{EXPERIMENTAL PROGRAM}

\subsection{Test series}

The experimental program is composed of four RC slabs with a rectangular cross section of $120 \times 600 \mathrm{~mm}^{2}$, a total length of $2600 \mathrm{~mm}$ and a span length of $2400 \mathrm{~mm}$. The longitudinal steel reinforcement is consisted of $3 \mathrm{bars}$ of $6 \mathrm{~mm}$ diameter (3ф6) in the compression zone and 4 bars of $8 \mathrm{~mm}$ diameter $(4 \phi 8)$ in the tension surface. Steel stirrups of 6 mm diameter spaced at $300 \mathrm{~mm}(\phi 6 @ 300 \mathrm{~mm})$ are adopted for transversal steel reinforcement, and have the main purpose of maintaining the longitudinal reinforcement in the aimed position. The adopted reinforcement systems were 
designed to assure flexurally failure mode for all the tested slabs (reinforcement yielding). Fig. 1 represents the cross section geometry and reinforcement arrangement for each slab, as well as the longitudinal geometry, loading configuration and support conditions. The concrete clear cover of the longitudinal tensile bars was $20 \mathrm{~mm}$.

The general information of the four tested RC slabs is represented in Table 1. The SREF is the reference slab without CFRP, and the S2L-0, S2L-20 and S2L-40 slabs are those flexurally strengthened using two NSM CFRP laminates (Fig. 2) with different prestress level: 0\% (S2L-0), 20\% (S2L-20) and 40\% (S2L-40) of the ultimate tensile strength of the CFRP laminates. The CFRP laminates used in the present experimental program have a cross section of 1.4 (thickness) $\times 20($ depth $) \mathrm{mm}^{2}$. Table 1 shows that the tested slabs have a percentage of longitudinal tensile steel bars $\left(\rho_{s l}\right)$ of about $0.35 \%$, while the CFRP strengthening percentage $\left(\rho_{f}\right)$ is approximately $0.08 \%$.

The four point slab bending tests (Fig. 3) were executed under displacement control at a deflection rate of $0.02 \mathrm{~mm} / \mathrm{second}$. All slabs were instrumented to measure the applied load, deflections and strains in the CFRP laminates and longitudinal tensile steel reinforcement. Positions of the LVDTs (linear variable displacement transducers) and strain gauges (SG) in the monitored longitudinal tensile bars and in the NSM CFRP laminates are indicated in Fig. 4. The deflection of the slabs was measured by five displacement transducers (LVDT 1 to LVDT 5) according to the arrangement indicated in Fig. 4a. To evaluate the strains on the steel bars, three strain gauges were installed (Fig. 4b) on the two bottom longitudinal steel bars (SG-S1 to SG-S3). In the non-prestressed slab three strain gauges were installed on the two CFRP laminates (SG-L1 to SG-L3) according to the scheme represented in Fig. 4c, while in the prestressed slabs the disposition of the five strain gauges (SG-L1 to SG-L5) applied on two CFRP laminates is indicated in Fig. 4d (the SG-L4 and SG-L5 strain gauges were installed near the end of one CFRP laminate to determine prestress losses).

According to Fig. 4c, the length of the laminates in S2L-0 slab was $2300 \mathrm{~mm}$. For the RC slabs flexurally strengthened with prestressed laminates the slits were executed along the total length of the slab, but in the extremities of the laminates were not bonded to the concrete in a length of $150 \mathrm{~mm}$, in order to provide the same bond length adopted in the S2L-0 slab.

\subsection{Materials}

The compressive strength [15] and Young's modulus [16] of the concrete were evaluated at the age of the slab tests (294 days), carrying out direct compression tests with cylinders of $150 \mathrm{~mm}$ diameter and $300 \mathrm{~mm}$ height. The values of the main tensile properties of the high bond steel bars (6 and $8 \mathrm{~mm}$ diameter) used in the tested slabs were obtained from uniaxial tensile tests performed according to the recommendations of EN 10002 [17]. The tensile properties of the 
CFK 150/2000 S\&P laminates were characterized by uniaxial tensile tests carried out according to ISO 527-5 [18].

Table 2 includes the average values obtained from these experimental programs.

S\&P Resin 220 epoxy adhesive was used to bond the CFRP laminates to the concrete substrate. The instantaneous and long term tensile behavior of this adhesive was investigated by Costa and Barros [19]. At 3 days, at which the elasticity modulus $\left(\boldsymbol{E}_{\mathbf{0 . 5} \sim 2.5 \%}\right)$ has attained a stabilized value, the tensile strength and the $\boldsymbol{E}_{\boldsymbol{0 . 5}} \mathbf{2 . 5}_{\% \boldsymbol{0}}$, determined according to the ISO 527-2 recommendations [20], was about $20 \mathrm{MPa}$ and $7 \mathrm{GPa}$, respectively.

\subsection{Application of the NSM CFRP laminates}

To apply the passive CFRP laminates using NSM technique, the following procedures were executed: 1) using a diamond cutter, slits of about $5 \mathrm{~mm}$ width and $25 \mathrm{~mm}$ depth were opened on the concrete cover of the tension face according to the pre-defined arrangement for the laminates; 2) the slits were cleaned by compressed air; 3) the laminates were cut with the desired length and cleaned with acetone; 4) the epoxy adhesive was produced according to the supplier recommendations; 5) the slits were filled with the adhesive; 6) an adhesive layer was applied on the faces of the laminates; and 7) the laminates were inserted into the slits and adhesive in excess was removed.

Fig. 5 shows the device for applying the prestressing force, which include the main system to apply the pressure into the hoses, handle for controlling the oil pressure, hydraulic hollow jacks for transferring force to the laminates and load cells that were installed between hydraulic jacks and main frame to control the value of prestressing load. The design details of the mechanical components of this prestressing system can be consulted elsewhere [21]. After installing the slab in the right position of prestressing line, the CFRP laminates were installed into the slits (that were previously opened on the concrete cover of the tension face) and passed through the hydraulic jacks and load cells, and were anchored in both extremities by using an active and a passive anchor, as is shown in the Fig. 5. Each laminate was installed in the middle of the slit, as closest as possible to the slab's external surface, and then the prestressing force was applied.

In S2L-20 and S2L-40 slabs the prestressing load for each laminate was about, respectively, $20 \%$ and $40 \%$ of the laminate tensile strength. The prestressing force was applied to one extremity of laminate by the hydraulic jack, while the other extremity of the CFRP laminate remained fixed to the main frame of prestress line by using steel anchors. The increase of the prestressing load was about $0.5 \mathrm{kN} / \mathrm{min}$.

When the prestressing load was completely applied to the laminates, epoxy adhesive was applied into the slits by using a spatula, as shown in Fig. 5. Special care was taken in the execution of this task in order to avoid the formation of the voids in the concrete-adhesive-CFRP interfaces, as well as into the adhesive layer. After curing the adhesive (about seven days), the prestressing load was released slowly and simultaneously in both CFRP laminates at a load rate of about $0.3 \mathrm{kN} / \mathrm{min}$. 
Fig. 6 show variations of strains on the CFRP laminates during less than one day after releasing the prestressing loads on the prestressed strengthened slabs. Table 3 shows the decrease of strains (in terms of percentage of the initial prestress strain) at the end of 24 hours after releasing the prestress on the CFRP laminates. This decrease is due to the loss of prestress in consequence of the deformability of the adhesive layer, concrete deformability and eventual sliding at concrete-adhesive-laminate interfaces. As this table shows, when the prestressing loads were released, the strain gauge closest to the free extremity of the laminate (SG-L5, that was at a distance of $25 \mathrm{~mm}$ far from this extremity) recorded a strain loss of about 40\% and 47\% in the S2L-20 and S2L-40 slabs, respectively. The rest of the strain gauges showed a loss of strain less than $6.3 \%$ for both slabs, which indicated that the main part of the prestressing load was transformed to the concrete slab as expected.

\section{EXPERIMENTAL RESULTS AND DISCUSSION}

\subsection{Load carrying capacity of the tested slabs}

Fig. 7 shows the relationship between the applied force and the deflection at mid-span, $F-u$, for the tested RC slabs. This figure shows that the experimental load-displacement curves of the slabs have three important phases, until cracking of the concrete, between concrete cracking and yield initiation of the steel reinforcement, and between steel reinforcement yield initiation and ultimate load. As expected, the unstrengthened control slab behaved in a plastic manner in the third phase. The almost linear slop of the third phase of strengthened slabs is due to the contribution of the CFRP, since the laminates have linear behavior, while steel reinforcement is in a plastic stage and cracked concrete is too damaged. In fact, above the deflection corresponding to yield initiation, the load carrying capacity of the strengthened slabs has increased up to the CFRP rupture, after which the load dropped to that of the control slab. Regardless the prestress level of the laminates (0\%, 20\% and 40\%), the adopted CFRP configuration provided an increase in the slab's load carrying capacity at serviceability and ultimate limit states.

Table 4 shows the summary of the results of the tested RC slabs in terms of service $\left(F_{\text {serv. }}\right)$, yielding $\left(F_{s y}\right)$ and maximum $\left(F_{\max }\right)$ load (see also Fig.7). The values of the deflection at mid-span for the loads $F_{s y}\left(\delta_{F s y}\right)$ and $F_{\text {max }}\left(\delta_{F m a x}\right)$ are also indicated in Table 4. The service load $\left(F_{\text {serv }}\right)$ is the load corresponding to the maximum allowed deflection for serviceability limit states $\left(\delta_{F s e r v}\right)$, which according to the Eurocode 2 [22] is $l / 250$, where $l$ is the slab span length $(l / 250$ $=2400 \mathrm{~mm} / 250=9.6 \mathrm{~mm}$ ). The yielding load is herein defined as the load at which a considerable decay of stiffness has occurred.

Based on Table 4, the values of service load of reference, non-prestressed, $20 \%$ and $40 \%$ prestressed slabs are respectively, $15.89 \mathrm{kN}, 19.76 \mathrm{kN}, 24.65 \mathrm{kN}$ and $34.76 \mathrm{kN}$, which evidence the benefits of applying the CFRP laminates with a certain prestress. Strengthening the RC slabs with NSM CFRP laminates resulted in higher yielding loads than 
the $F_{s y}$ of the reference slab. The $F_{s y}$ has increased with the prestress level. The values of maximum load of strengthened slabs ranged between $51.8 \mathrm{kN}$ and $56.9 \mathrm{kN}$, which is 2.3 and 2.5 times higher the maximum load of the reference slab $(22.6 \mathrm{kN})$. The deflection at yield initiation and at maximum load has a tendency to decrease with the increase of the prestress level. Since the load at crack initiation increases with the prestress level, and considering the stiffness and load amplitude between crack initiation and yield initiation do not change significantly with the prestress level, the deflection at yield initiation decreases. By increasing the prestress level, larger initial strains are introduced in the CFRP laminates. Due to this fact and considering the CFRP has ruptured at maximum load, the corresponding deflection has decreased with the prestress level.

\subsection{Crack pattern and failure modes}

Fig. 8 shows the final crack pattern of the tested RC slabs. By strengthening RC slabs with NSM CFRP laminates, the average distance between cracks and the crack width have decreased. When the final crack pattern of the NSM slabs is compared, it is possible to conclude that the length of the slab's cracked band has decreased with the increase of the prestress level. This means that the loss of flexural stiffness due to crack initiation and propagation has decreased with the increase of prestress level, which is visible in the elasto-cracked stage of the F-u response, since the stiffness at this stage has increased with the prestress level. This increase was, however, small due to the relatively low axial load applied by the CFRP prestressed laminates to the tested slabs.

Two types of failure modes occurred in the tested RC slabs: 1) the reference slab failed by the concrete crushing after the yielding of the tensile steel reinforcements (see Fig. 9a); 2) the strengthened slabs failed by the rupture of the CFRP (see Fig. 9b) after the yielding of the tensile steel reinforcements.

\subsection{Strains in CFRP}

The maximum values of strain recorded in the strain gauges installed in the CFRP laminates up to the maximum load $\left(F_{\max }\right)$ of the slabs are indicated in the column "Total" of the Table 5. Each of these values is the addition of the strain at the end of the prestress phase (column "Prestressing") with the maximum strain registered in the loading phase of the slab up to its $F_{\max }$ (column "Test"). The maximum values of strain measured in the CFRP laminates (column "Total"), namely in the SG-L2, are quite close to the ultimate tensile strain of the CFRP, justifying the failure mode of the strengthened slabs and the high effectiveness of the NSM technique for the flexural strengthening of RC slabs. Based on this table, with increasing the level of prestress, total strain in the CFRP laminates increase that shows with increasing the level of prestress, the probability of using of more capacity of CFRP laminates increase.

Fig. 10 shows the relationship between the applied load and the strain in the SG-L2 strain gauge. As this figure shows, the initial strain of CFRP laminates for $0 \%, 20 \%$ and $40 \%$ prestressed slabs are respectively, $0,3.34$ and $6.93 \%$ 
that was indicated in Table 5. According to the Fig. 10, the load-CFRP strain curves of the slabs have the same three important phases that were above mentioned in the analysis of the Fig. 7: 1) until cracking of the concrete, where the variation is almost null; 2) between concrete cracking and yield initiation of the steel reinforcement, where the strain has increased with the load; 3) and between steel reinforcement yield initiation and ultimate load, with an almost equal strain gradient in all the slabs, which is much more pronounced than in the previous phase, due to the plastic stage of the steel reinforcement.

\subsection{Effect of the prestress}

To evaluate the effect of the prestress level of CFRP laminates on the overall flexural behavior of RC slabs, the values of forces $\left(F_{\text {serv }}^{S t r} ; F_{\max }^{S t r}\right)$ and corresponding deflections $\left(\delta_{F_{\max }}^{S t r}\right)$ of the strengthened prestressed slabs are compared in Table 6 with those values of the reference slab $\left(F_{\text {serv }}^{R e f} ; F_{\max }^{R e f} ; \delta_{F_{\max }}^{R e f}\right)$. The obtained results evidence that applying a prestress level of 0\%, 20\% and 40\% in the CFRP laminates has provided an increase of, respectively, 24.35\%, 55.13\% and $118.75 \%$ in service load, and an increase of, respectively, $129.20 \%, 135.97 \%$ and $151.77 \%$ in maximum load. However, the maximum deflection has decreased in $45.68 \%, 59.96 \%$ and $73.26 \%$ by applying a prestress level of $0 \%$, $20 \%$ and $40 \%$. Nonetheless, the decrease of $\delta_{F s y}$ for the S2L-20 and S2L-40 was only $2 \%$ and $13 \%$, while at $\delta_{F m a x}$ both the prestressed slabs had already experienced a large incursion on the plastic stage of the steel reinforcement, therefore the level of ductility is still significantly high in the prestressed slabs.

Fig. 11 shows the effect of increasing the prestressing level on the service, yielding and ultimate loads with respect to the reference slab, SREF, and the non-prestressed strengthened slab, S2L-0. This figure clearly evidences the pronounced favorable effect of the prestress level in terms of load carrying capacity of RC slabs at serviceability and at yield initiation stages, while the increase of ultimate load was not significantly affected by the prestress level adopted.

Fig. 12 represents the effect of increasing the prestress leves on the deflection at yielding and ultimate loads. When compared with these values recorded in the SREF and S2L-0 slabs, it is verified a significant decrease of deflection capacity with the increase of the prestress level.

Fig. 13 shows the relation between the prestressing level and the energy consumed during the loading process of the slabs up to the deflection corresponding to the rupture of the CFRP laminates. This energy concept was calculated as the area under the load-deflection curve. It is observed an almost linear decrease of the energy consumed with the increase of the prestress level. 


\section{Numerical simulation}

Previous work [8] shown that, using a cross section layered model that takes into account the constitutive laws of the intervening materials, and the kinematic and the equilibrium conditions, the deformational behavior of structural elements failing in bending can be predicted from the moment-curvature relation, $\mathrm{M}-\chi$, of the representative cross sections of these elements, using the algorithm described elsewhere [23, 24].

To evaluate the $\mathrm{M}-\chi$ relationship, the slab cross section was discretized in layers of $1 \mathrm{~mm}$ thick. To simulate the behavior concrete in compression, the stress-strain relationship recommended by model code CEB-FIP Model Code 90 [25] was used (see Fig. 14a). Concrete was assumed as behaving linearly up to its tensile strength, while in the postcracking stage the trilinear tension-stiffening diagram, represented in Fig. 14b and investigated by Barros and Fortes [8], was used. In this figure, $f_{c t m}$ is average concrete tensile strength determined from the average compressive strength, $f_{c m}$; by adopting the Eurocode 2 [22] recommendations. The considered values for the parameters $\alpha_{1}$ and $\zeta_{1}$ were, respectively, 0.55 and 3 .

The stress-strain diagram used to model the tension and the compression behavior of steel bars is represented in Fig. 15 [8]. The data defining this relationship is indicated in Table 7. For modeling the tensile behavior of the CFRP laminates, a linear elastic stress-strain relationship was adopted, by using the values indicated in Table 2.

Fig. 16 compares the relationship between the applied load and the deflection at mid-span recorded experimentally and obtained in the numerical simulations. As Fig. 16 shows, the adopted numerical strategy fits with enough accuracy the registered experimental load $v s$. mid-span deflection curves of the tested slabs.

\section{Conclusions}

By carrying out an experimental program, the influence of the prestressed level applied to CFRP laminates in the behavior of RC slabs flexurally strengthened with NSM technique was investigated. From the obtained experimental results it can be concluded that:

- Regardless the prestress level of the CFRP laminates, the NSM technique with CFRP laminates is highly effective for the flexural strengthening of RC slabs. In fact, the adopted CFRP flexural strengthening configuration has provided an increase in terms of maximum load that ranged between $129 \%$ and $152 \%$ of the maximum load of the reference RC slab.

- By strengthening RC slabs with prestressed NSM CFRP laminates resulted in a significant increase of load carrying capacity at serviceability and ultimate limit states. By applying $20 \%$ of prestress in the NSM CFRP laminates, the 
service and ultimate loads have increased, respectively, $55 \%$ and $136 \%$ when compared to the corresponding values of the reference slab, while $40 \%$ of prestress, has guaranteed an increase of $119 \%$ and $152 \%$.

- By increasing the prestress level in the NSM CFRP laminates the overall flexural behavior of the slabs at service and ultimate states has improved, but the deflection at the maximum load and at yield initiation of the steel reinforcement of the slabs has decreased with the increase of the prestress level. However, the deflection at maximum load was more than two times the deflection at yield initiation, with a significant plastic incursion on the steel reinforcement, which assures the required level of deflection ductility for this type of RC structures.

- Regardless the prestress level applied to the CFRP laminates, all the strengthened slabs failed by rupture of the laminates after yielding of the tension steel reinforcement. This failure mode proved the high effectiveness of the NSM technique for the flexural strengthening of RC slabs.

A numerical strategy was used to evaluate the load-deflection of the tested RC slabs. Using the properties of the intervening materials in the tested slabs, obtained from experimental tests, the relationship between the force and the mid-span deflection recorded in the tested slabs was predicted with high accuracy, revealing that the adopted numerical strategy is appropriate to simulate the behavior of RC slabs strengthened by NSM technique with CFRP laminates with or without prestress.

\section{ACKNOWLEDGEMENTS}

The authors wish to acknowledge the materials provided by $\mathrm{S} \& \mathrm{P} \circledast$ and Secil (Unibetão, Braga). This work was supported by FEDER funds through the Operational Program for Competitiveness Factors - COMPETE and National Funds through FCT - Portuguese Foundation for Science and Technology under the project Prelami PTDC/ECM/114945/2009. The first authors acknowledge the grant provided under the framework of this project.

\section{REFERENCES}

[1] ACI Committee 440, "Guide for the design and construction of externally bonded FRP systems for strengthening concrete structures”, American Concrete Institute, 118 pp. (2002).

[2] fib - Bulletin 14, “Externally bonded FRP reinforcement for RC structures”, Technical report by Task Group 9.3 FRP (Fiber Reinforced Polymer) reinforcement for concrete structures, Féderation Internationale du Béton - fib, July, 130 pp. (2001).

[3] Bakis, C.E., Bank, L.C., Brown, V.L., Cosenza, E., Davalos, J.F., Lesko, J.J., Machida, A., Riskalla, S.H. and Triantafillou, T.C., "Fiber-reinforced polymer composites for construction - state-of-the-art review”, Journal of Composites for Construction, 6(2), 73-87 (2002).

[4] Blaschko, M. e Zilch, K., "Rehabilitation of concrete structures with CFRP strips glued into slits”, Proceedings 
of the Twelfth International Conference of Composite Materials, ICCM 12, Paris, France (CD-ROM) (1999).

[5] El-Hacha, R. and Riskalla, S.H., "Near-surface-mounted fiber-reinforced polymer reinforcements for flexural strengthening of concrete structures”, ACI Structural Journal, 101(5), 717-726 (2004).

[6] Barros, J.A.O., Dias, S.J.E. and Lima J.L.T., “Efficacy of CFRP-BASED techniques for the flexural and shear strengthening of concrete beams", Journal Cement \& Concrete Composites, Volume 29, Issue 3, March, pp. 203-217 (2007).

[7] Carolin, A., "Carbon fibre reinforced polymers for strengthening of structural elements", Doctoral Thesis, Division of Structural Engineering, Luleå University of Technology, Lulea, Sweden, 190 pp. (2003).

[8] Barros, J.A.O. and Fortes, A.S., "Flexural strengthening of concrete beams with CFRP laminates bonded into slits", Journal Cement and Concrete Composites, 27(4) p. 471-480 (2005).

[9] Kotynia, R., “Analysis of the flexural response of NSM FRP-strengthened concrete beams”, $8^{\text {th }}$ International Symposium on Fiber Reinforced Polymer (FRP) Reinforcement for Concrete Structures (FRPRCS-8), Patras, Greece, July 16-18 (2007).

[10] Bonaldo, E., "Composite materials and discrete steel fibres for the strengthening of thin concrete structures", PhD Thesis, Department of Civil Engineering, University of Minho (2008).

[11] Barros, J.A.O., "Pre-stress technique for the flexural strengthening with NSM-CFRP strips", 9th International Symposium on Fiber Reinforced Polymer Reinforcement for Concrete Structures, Sydney, Australia, artigo 85, 13-15 July (2009).

[12] Badawi M. and Soudki K., "Flexural strengthening of RC beams with prestressed NSM CFRP rods Experimental and analytical investigation”, Construction and Building Materials Journal, 23, pp. 3292-3300 (2009).

[13] El-Hacha, R. and Gaafar M., "Flexural strengthening of reinforced concrete beams using prestressed, nearsurface-mounted CFRP bars”, PCI Journal, Fall 2011.

[14] Rezazadeh, M., Costa, I.G. and Barros, J.A.O., “Assessment of the Effectiveness of Prestressed NSM CFRP Laminates for the Flexural Strengthening of RC Beams", $11^{\text {th }}$ International Symposium on Fiber Reinforced Polymer (FRP) Reinforcement for Concrete Structures (FRPRCS-11), Guimarães (2013).

[15] EN 206-1, “Concrete - Part 1: Specification, performance, production and conformity”, European standard, CEN, 69 pp. (2000).

[16] LNEC E397-1993, “Concrete - Determination of the elasticity modulus under compression”, Portuguese specification from LNEC. (1993).

[17] EN 10002-1, “Metallic materials - Tensile testing. Part 1: Method of test (at ambient temperature)”, European Standard, CEN, Brussels, Belgium, 35 pp. (1990). 
[18] ISO 527-5, “Plastics - Determination of tensile properties - Part 5: Test conditions for unidirectional fibrereinforced plastic composites”, International Organization for Standardization (ISO), Geneva, Switzerland, 9 pp. (1997).

[19] Costa, I.G. and Barros, J.A.O., "Assessment of the long term behavior of structural adhesives in the context of NSM flexural strengthening technique with prestressed CFRP laminates", $11^{\text {th }}$ International Symposium on Fiber Reinforced Polymer (FRP) Reinforcement for Concrete Structures (FRPRCS-11), Guimarães (2013).

[20] ISO 527-2, "Plastics - Determination of tensile properties - Part 2: Test conditions for moulding and extrusion plastics", International Organization for Standardization, 1993.

[21] Costa, I.G.; Barros, J.A.O., "Design and development of hydraulic-electro-mechanical system to apply prestressed CFRP laminates according to the NSM technique in laboratory conditions", Technical Report no. 12 DEC/E-10, University of Minho, 59 pp, March (2012).

[22] EN 1992-1-1, "Eurocode2: Design of Concrete Structures Parte 1-1: General Rules for Buildings", CEN, Brussels, Belgium, (2004)

[23] Barros, J.A.O., Taheri, M., Salehian, H. and Mendes P.J.D., 2012, "A design model for fibre reinforced concrete beams pre-stressed with steel and FRP bars", Composite Structures, 94, 2494-2512.

[24] Barros, J.A.O., Oliveira, J.T., Lourenço, P.J.B., Bonaldo, E., “Flexural behavior of reinforced masonry panels”, ACI Structural Journal, 103(3), May, pp. 418-426 (2006).

[25] CEB-FIP Model Code. Comite Euro-International du Beton, Bulletin d'Information n 213/214, 1993.

\section{TABLES AND FIGURES}

\section{List of Tables:}

Table 1 - General information of the tested RC slabs.

Table 2 - Values of the properties of the intervening materials.

Table 3 - Values of loss of straind in S2L-20 and S2L-40

Table 4 - Summary of the results in terms of loads and deflections.

Table 5 - Maximum values of strain recorded in CFRP laminate's strain gauges up to the maximum load of the slabs.

Table 6 - Comparison of the results with the reference slab.

Table 7 - Properties of the steel bars used in the numerical simulation. 


\section{List of Figures:}

Fig. 1 - General information about the tested RC slabs (dimensions in $\mathrm{mm}$ ).

Fig. 2 - Cross-section of the RC slabs strengthened with NSM CFRP laminates (dimensions in mm).

Fig. 3 - Test set up.

Fig.4 - Positions of the: a) displacement transducers (LVDTs); b) strain gauges in the monitored longitudinal tensile bars; c) strain gauges in the NSM CFRP laminates of non-prestressed slab; d) strain gauges in the NSM CFRP laminates of prestressed slabs (dimensions in $\mathrm{mm}$ ).

Fig. 5 - Application of the prestress in the NSM CFRP laminates.

Fig. 6 - Strains in the CFRP vs. time after releasing the prestress load in: a) S2L-20; and b) S2L-40.

Fig. 7 - Force vs. deflection at mid-span of the tested RC slabs.

Fig. 8 - Cracking patterns of the tested RC slabs.

Fig. 9 - Failure modes of the tested RC slabs.

Fig. 10 - Load vs. strain in CFRP laminate (SG-L2, Fig. 4).

Fig. 11 - Effect of prestressing level on service, yielding and ultimate loads of the RC slabs.

Fig. 12 - Effect of prestressing level on yielding and ultimate deflection of the RC slabs.

Fig. 13 - Effect of increasing the prestressing level on the ductility of the RC slabs.

Fig. 14 - Concrete laws used in the numerical simulation: (a) in compression [23]; (b) in tension [8].

Fig. 15 - Stress-strain relationship for the steel bars [8].

Fig. 16 - Experimental vs. numerical force-deflection at mid-span for the tested RC slabs: a) SREF, b) S2L-0, c) S2L20, d) S2L-40. 
Table 1 - General information of the tested RC slabs.

\begin{tabular}{|c|c|c|c|c|}
\hline \multirow[b]{2}{*}{ Slab } & \multirow{2}{*}{$\begin{array}{c}\rho_{s l} \\
{[\%]^{(1)}}\end{array}$} & \multicolumn{2}{|c|}{ NSM CFRP flexural strengthening } & \multirow[b]{2}{*}{ Level of prestress (\%) } \\
\hline & & Quantity & $\begin{array}{c}\rho_{f} \\
{[\%]^{(2)}}\end{array}$ & \\
\hline SREF & \multirow{4}{*}{0.349} & - & - & - \\
\hline S2L-0 & & \multirow{3}{*}{$\begin{array}{c}2 \text { CFRP laminates with } 1.4 \times 20 \mathrm{~mm}^{2} \text { of } \\
\text { cross section } \\
\left(A_{f}=2 \times 1.4 \times 20=56 \mathrm{~mm}^{2}\right)\end{array}$} & \multirow{3}{*}{0.077} & 0 \\
\hline S2L-20 & & & & 20 \\
\hline S2L-40 & & & & 40 \\
\hline
\end{tabular}

(1) The percentage of the longitudinal tensile reinforcement was obtained from $\rho_{s l}=\left(A_{s l} /\left(b_{w} \times d\right)\right) \times 100$, where $A_{s l}$ is the cross sectional area of the longitudinal tensile steel reinforcement (see Fig. 1), $b_{w}=600 \mathrm{~mm}$ is the width of the slab's cross section, and $d$ is the distance from extreme compression fibre to the centroid of tensile reinforcement. (2) The CFRP percentage was obtained from $\rho_{f}=\left(A_{f} / A_{c}\right) \times 10 O$, where $A_{f}$ is the cross sectional area of the NSM CFRP laminates and $A_{c}$ is the concrete cross sectional area.

Table 2 - Values of the properties of intervening materials.

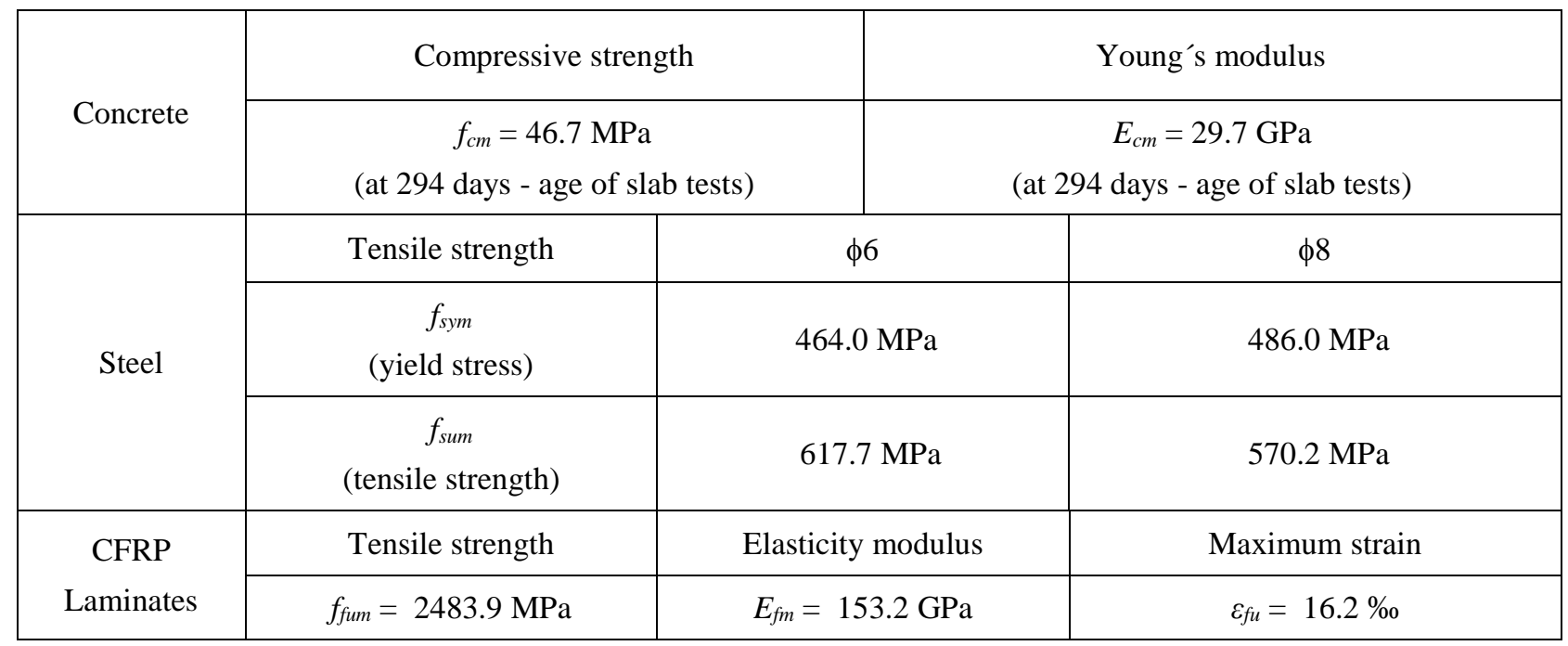

Table 3 - Values of loss of strain in S2L-20 and S2L-40 after 24 hours of prestress releasing.

\begin{tabular}{|c|c|c|c|c|c|}
\hline \multirow{2}{*}{ Slab } & \multicolumn{5}{|c|}{ Strain loss (\%) } \\
\cline { 2 - 6 } & SG-L1 & SG-L2 & SG-L3 & SG-L4 & SG-L5 \\
\hline S2L-20 & 3.04 & 4.65 & 5.47 & 6.29 & 40.12 \\
\hline S2L-40 & 1.22 & 0.73 & 1.05 & 4.75 & 47.10 \\
\hline
\end{tabular}


Table 4 - Summary of the results in terms of loads and deflections.

\begin{tabular}{|c|c|c|c|c|c|}
\hline \multirow{2}{*}{ Slab } & Service & \multicolumn{2}{|c|}{ Yielding } & \multicolumn{2}{c|}{ Maximum } \\
\cline { 2 - 6 } & $\begin{array}{c}F_{\text {serv. }} \\
(\mathrm{kN})\end{array}$ & $\begin{array}{c}F_{\text {sy }} \\
(\mathrm{kN})\end{array}$ & $\begin{array}{c}\delta_{F s y} \\
(\mathrm{~mm})\end{array}$ & $\begin{array}{c}F_{\max } \\
(\mathrm{kN})\end{array}$ & $\begin{array}{c}\delta_{F m a x} \\
(\mathrm{~mm})\end{array}$ \\
\hline SREF & 15.89 & 19.00 & 14.81 & 22.60 & 158.15 \\
\hline S2L-0 & 19.76 & 29.52 & 20.63 & 51.80 & 85.90 \\
\hline S2L-20 & 24.65 & 35.66 & 20.16 & 53.33 & 63.33 \\
\hline S2L-40 & 34.76 & 45.65 & 17.86 & 56.90 & 42.29 \\
\hline
\end{tabular}

Table 5 - Maximum values of strain recorded in CFRP laminates's strain gauges up to the maximum load of the slabs.

\begin{tabular}{|c|c|c|c|c|c|c|c|c|c|}
\hline \multirow{2}{*}{ Slab } & \multicolumn{3}{|c|}{ SG-L1(\%) } & \multicolumn{3}{c|}{ SG-L2(\%) } & \multicolumn{3}{c|}{ SG-L3(\%) } \\
\cline { 2 - 10 } & Prestressing & Test & Total & Prestressing & Test & Total & Prestressing & Test & Total \\
\hline S2L-0 & - & 13.90 & 13.90 & - & 15.03 & 15.03 & - & 3.95 & 3.95 \\
\hline S2L-20 & 2.68 & 11.96 & 14.64 & 3.34 & 11.86 & 15.20 & 2.74 & 2.36 & 5.10 \\
\hline S2L-40 & 6.45 & 9.33 & 15.78 & 6.93 & 9.19 & 16.12 & 6.41 & 1.53 & 7.94 \\
\hline
\end{tabular}

Table 6 - Performance of the NSM technique by considering relevant results of the strengthened and reference slabs.

\begin{tabular}{|c|c|c|c|}
\hline Slab & $\frac{F_{\text {serv }}^{\text {Str }}-F_{\text {serv }}^{\text {Ref }}}{F_{\text {serv }}^{\text {Ref }}} \times 100$ & $\frac{F_{\max }^{S t r}-F_{\max }^{R e f}}{F_{\max }^{R e f}} \times 100$ & $\frac{\delta_{F_{\max }}^{\text {str }}}{\delta_{F_{\max }}^{\text {Ref }}} \delta_{F_{\max }}^{\text {Ref }} \times 100$ \\
\hline S2L-0 & 24.35 & 129.20 & -45.68 \\
\hline S2L-20 & 55.13 & 135.97 & -59.96 \\
\hline S2L-40 & 118.75 & 151.77 & -73.26 \\
\hline
\end{tabular}

Table 7 - Properties of the steel bars used in the numerical simulation.

\begin{tabular}{|c|c|c|c|c|c|c|c|c|}
\hline $\begin{array}{c}\text { Bar diameter } \\
(\mathrm{mm})\end{array}$ & $E_{S}(\mathrm{GPa})$ & $\begin{array}{c}\varepsilon_{s} \\
(\mathrm{~mm} / \mathrm{mm})\end{array}$ & $\begin{array}{c}\sigma_{s 1} \\
(\mathrm{MPa})\end{array}$ & $\begin{array}{c}\varepsilon_{s 2} \\
(\mathrm{~mm} / \mathrm{mm})\end{array}$ & $\begin{array}{c}\sigma_{s 2} \\
(\mathrm{MPa})\end{array}$ & $\begin{array}{c}\varepsilon_{s 3} \\
(\mathrm{~mm} / \mathrm{mm})\end{array}$ & $\begin{array}{c}\sigma_{s 3} \\
(\mathrm{MPa})\end{array}$ & $\mathrm{P}$ \\
\hline 6,8 & 200 & 0.00236 & 472.5 & 0.03 & 500 & 0.15 & 570 & 3 \\
\hline
\end{tabular}



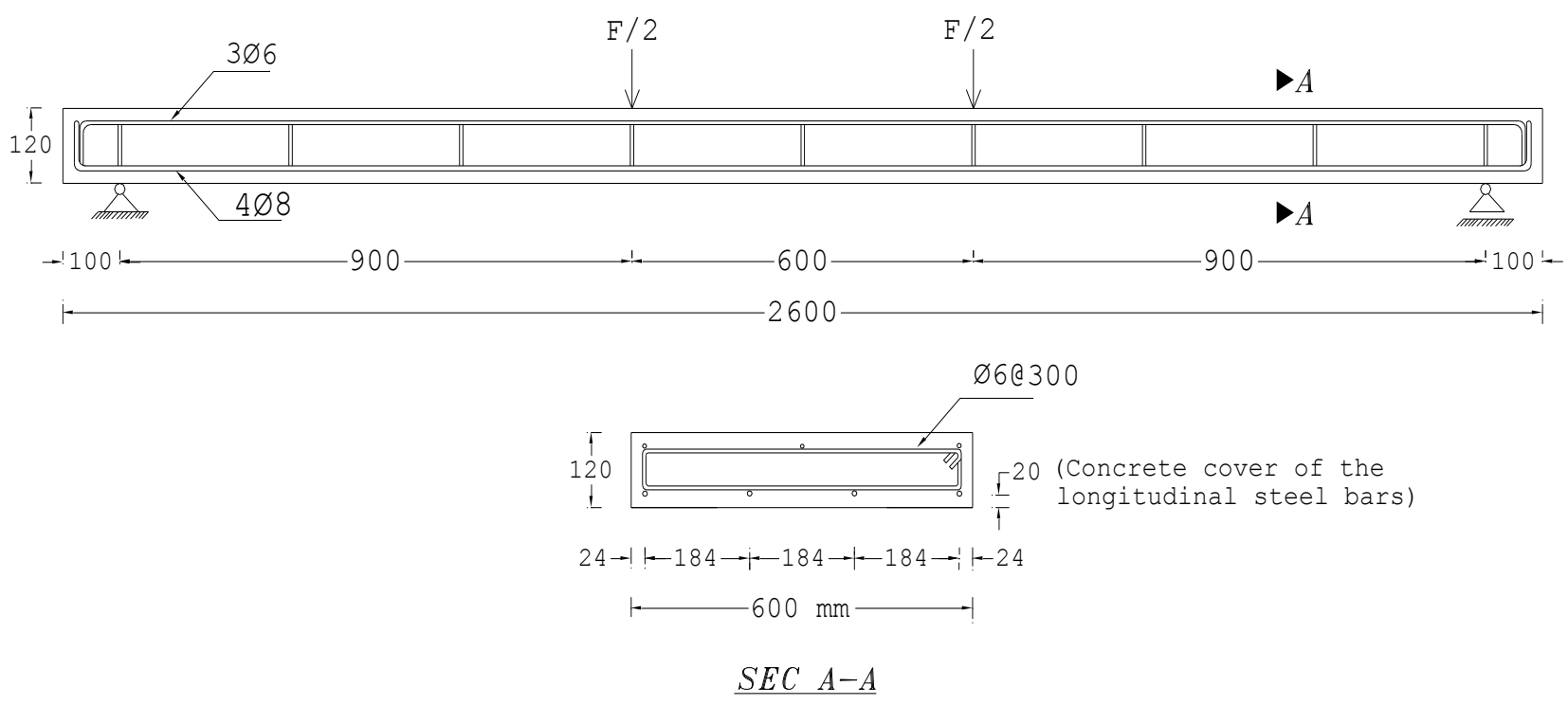

Fig. 1 - General information about the tested RC slabs (dimensions in $\mathrm{mm}$ ).

(2 NSM CFRP Laminates)

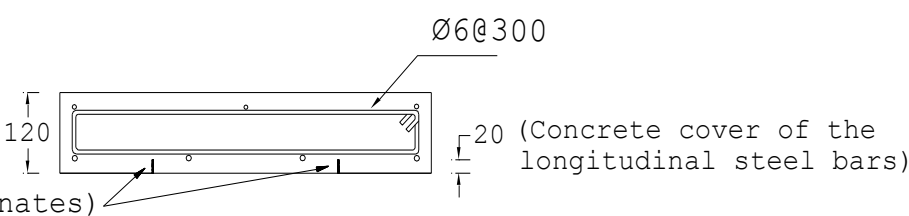

$1-150 \rightarrow-300 \longrightarrow 150 \rightarrow-1$

Fig. 2 - Cross-section of the RC slabs strengthened with NSM CFRP laminates (dimensions in mm).
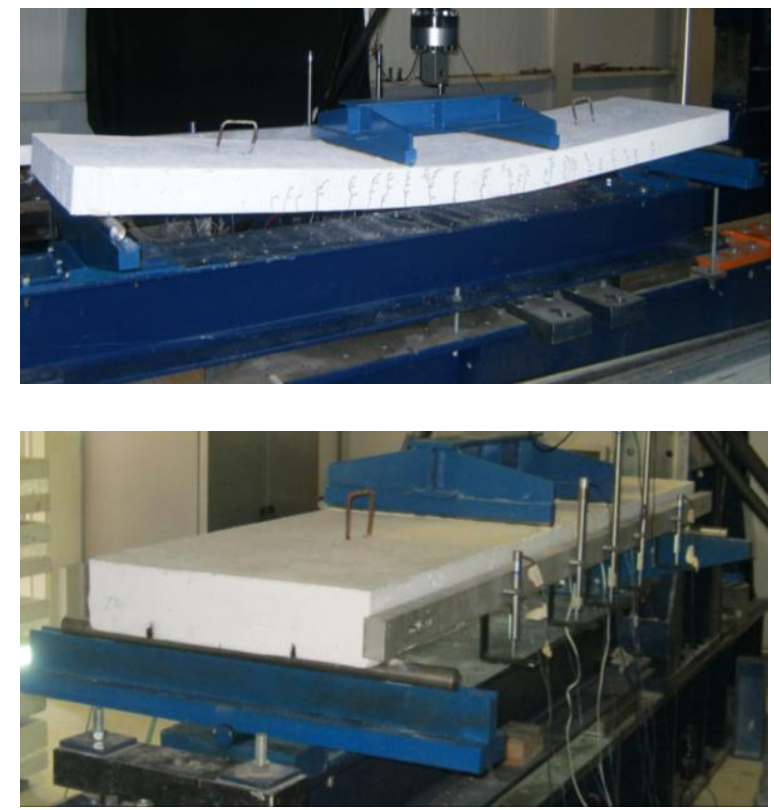

Fig. 3 - Test set up. 

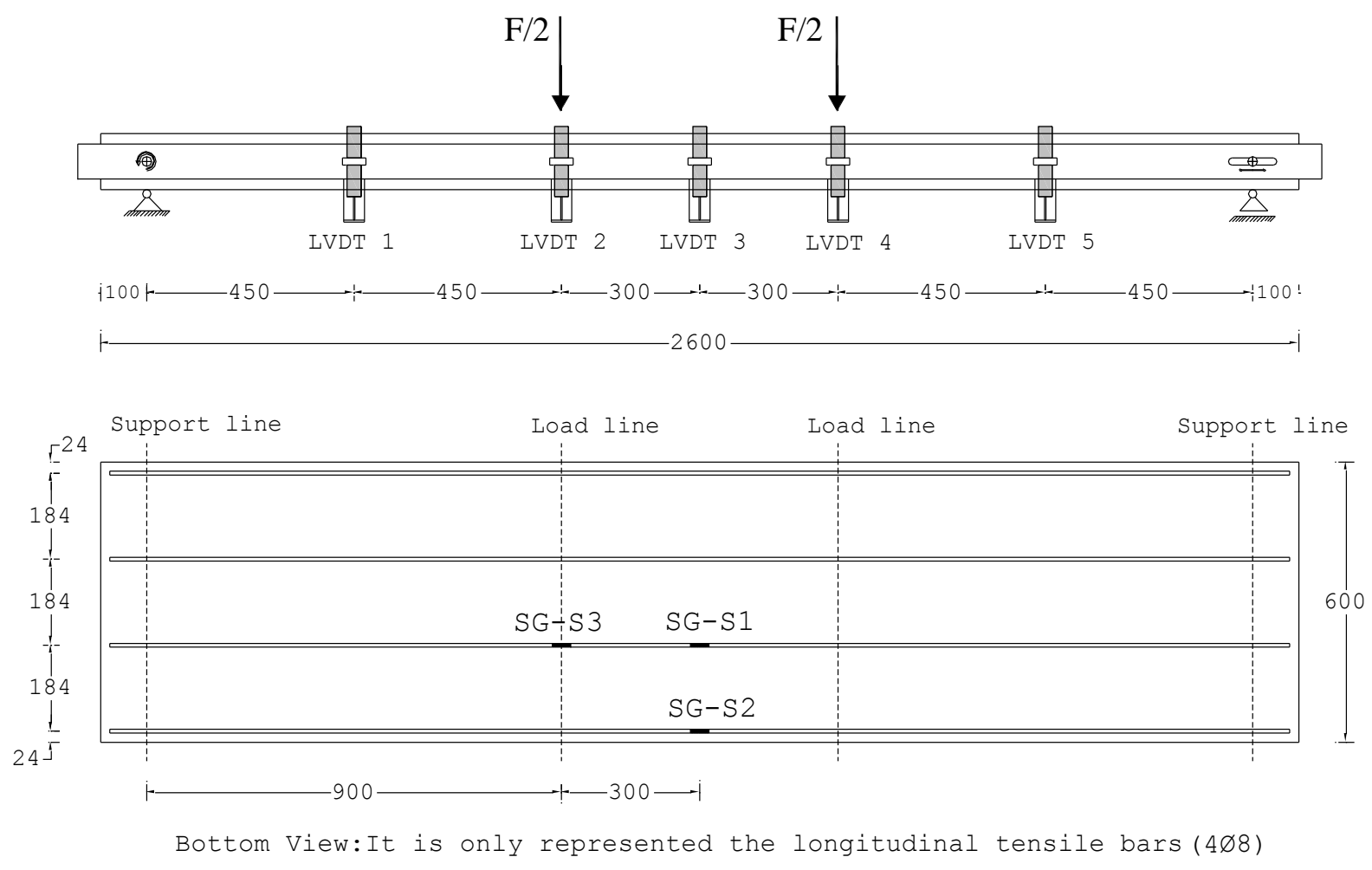

(b)
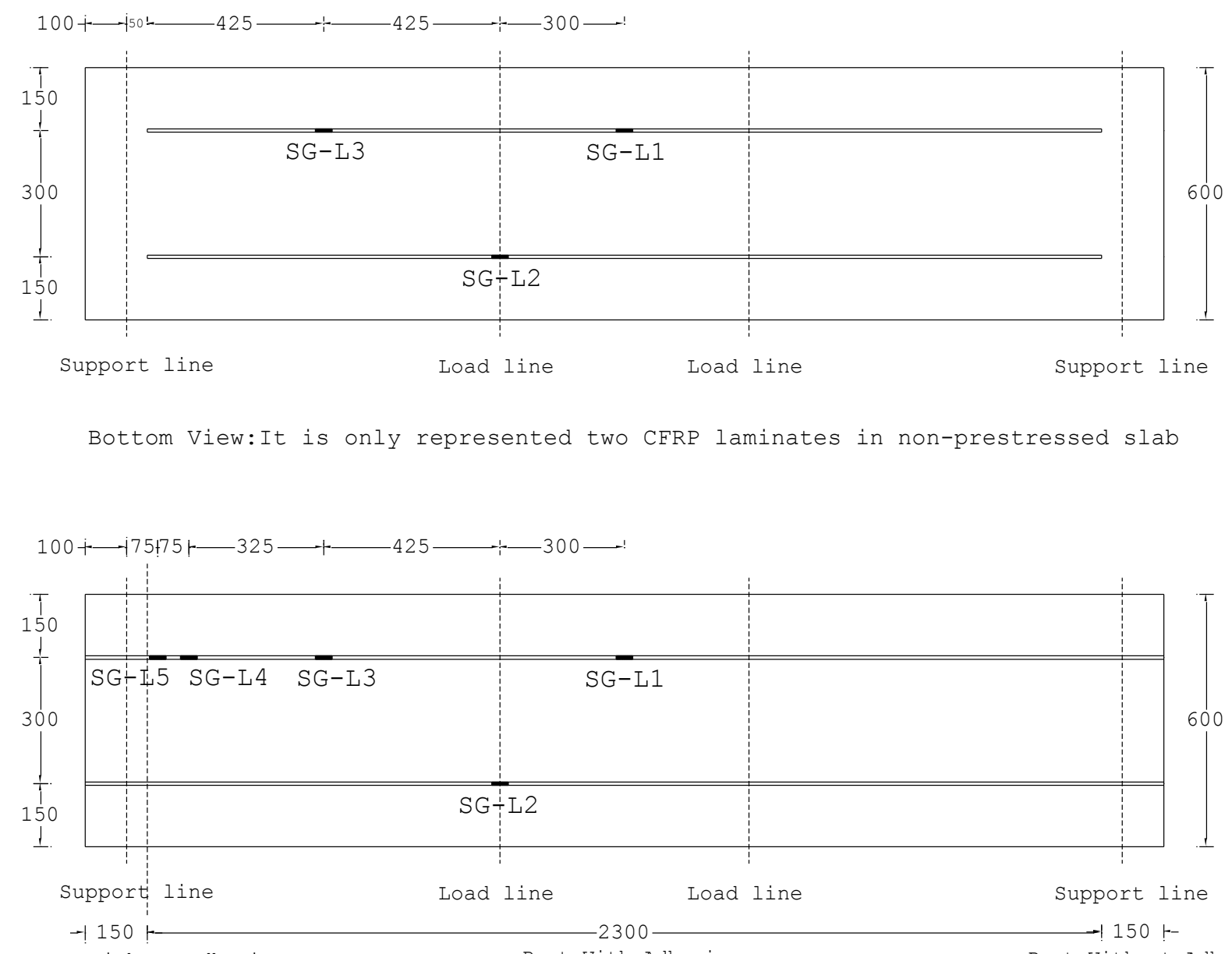

Bottom View: It is only represented two CFRP laminates in prestressed slabs

Fig. 4 - Positions of the: a) displacement transducers (LVDTs); b) strain gauges in the monitored longitudinal tensile bars; c) strain gauges in the NSM CFRP laminates of non-prestressed slab; d) strain gauges in the NSM CFRP laminates of prestressed slabs (dimensions in $\mathrm{mm}$ ). 


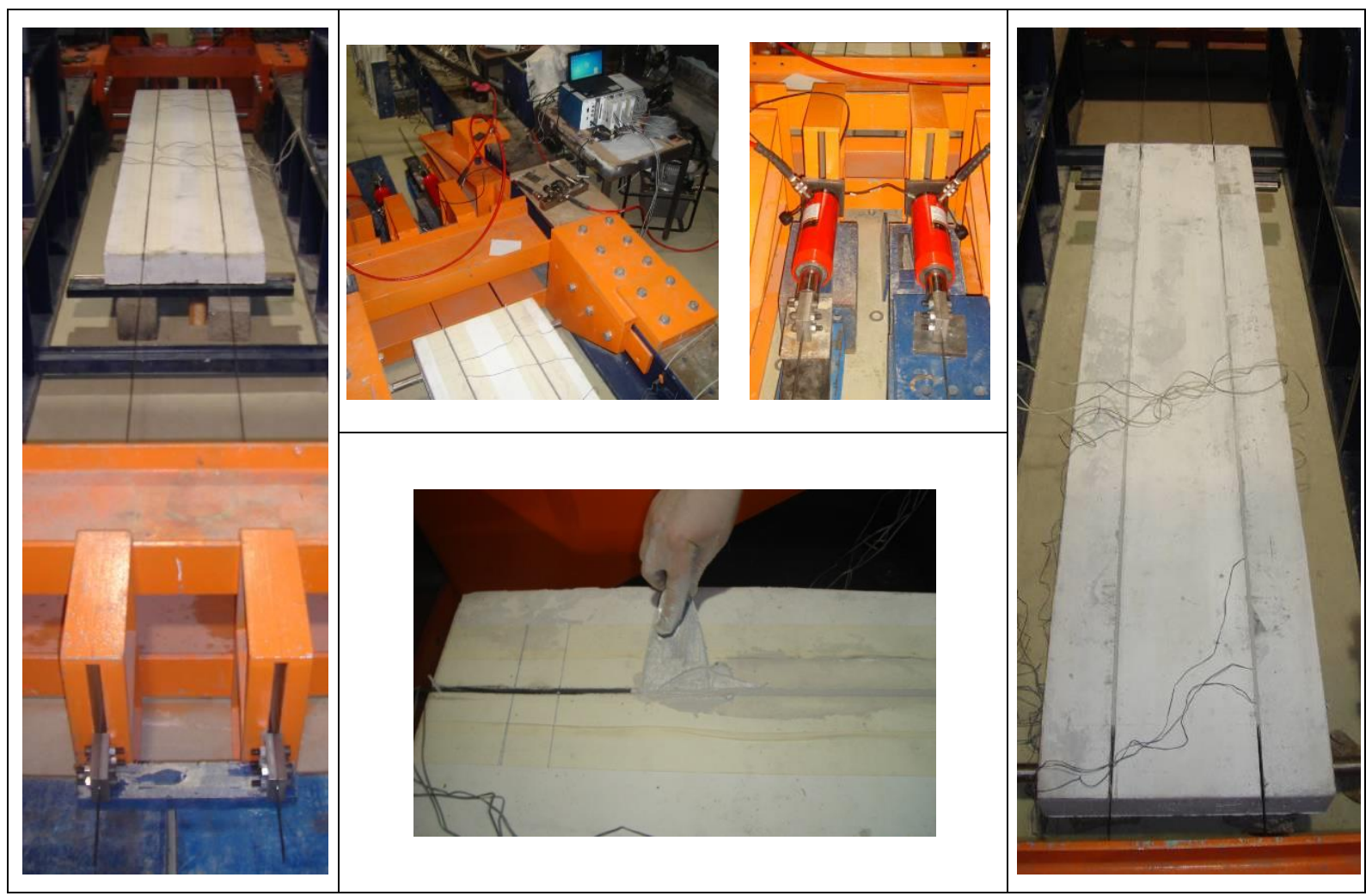

Fig. 5 - Application of the prestress in the NSM CFRP laminates.

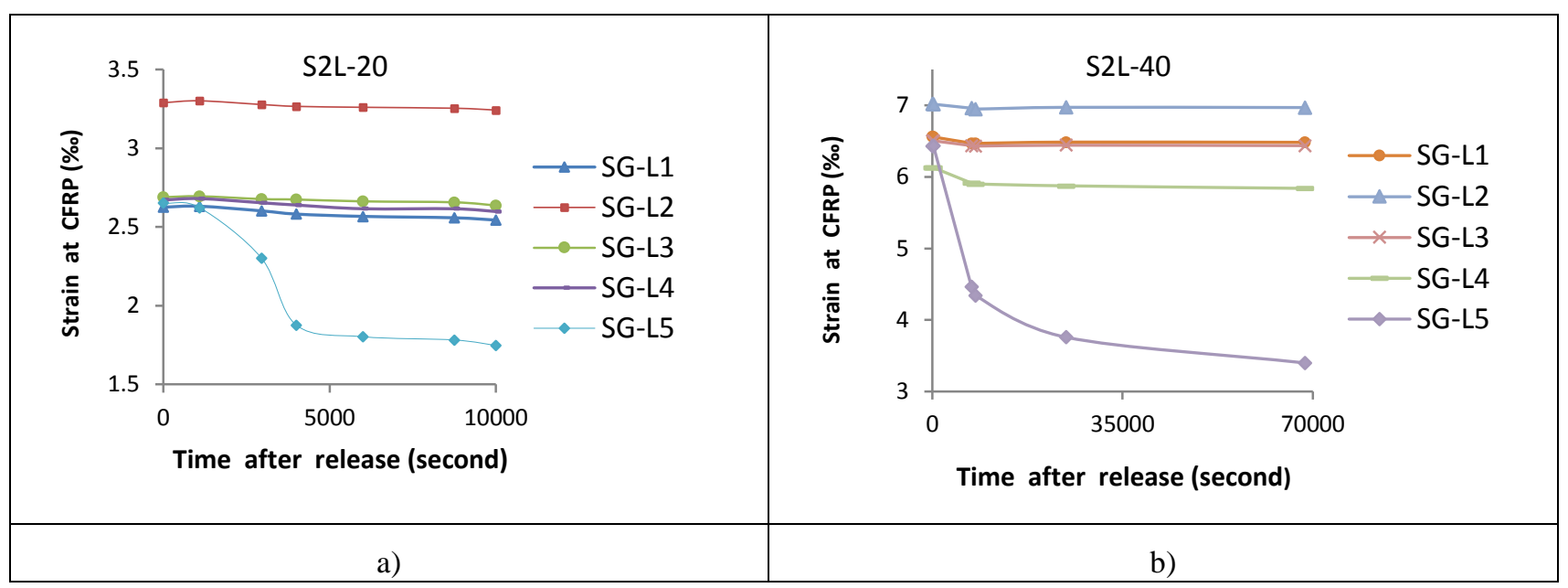

Fig. 6 - Strains in the CFRP vs. time after releasing the prestress load in: a) S2L-20; and b) S2L-40. 


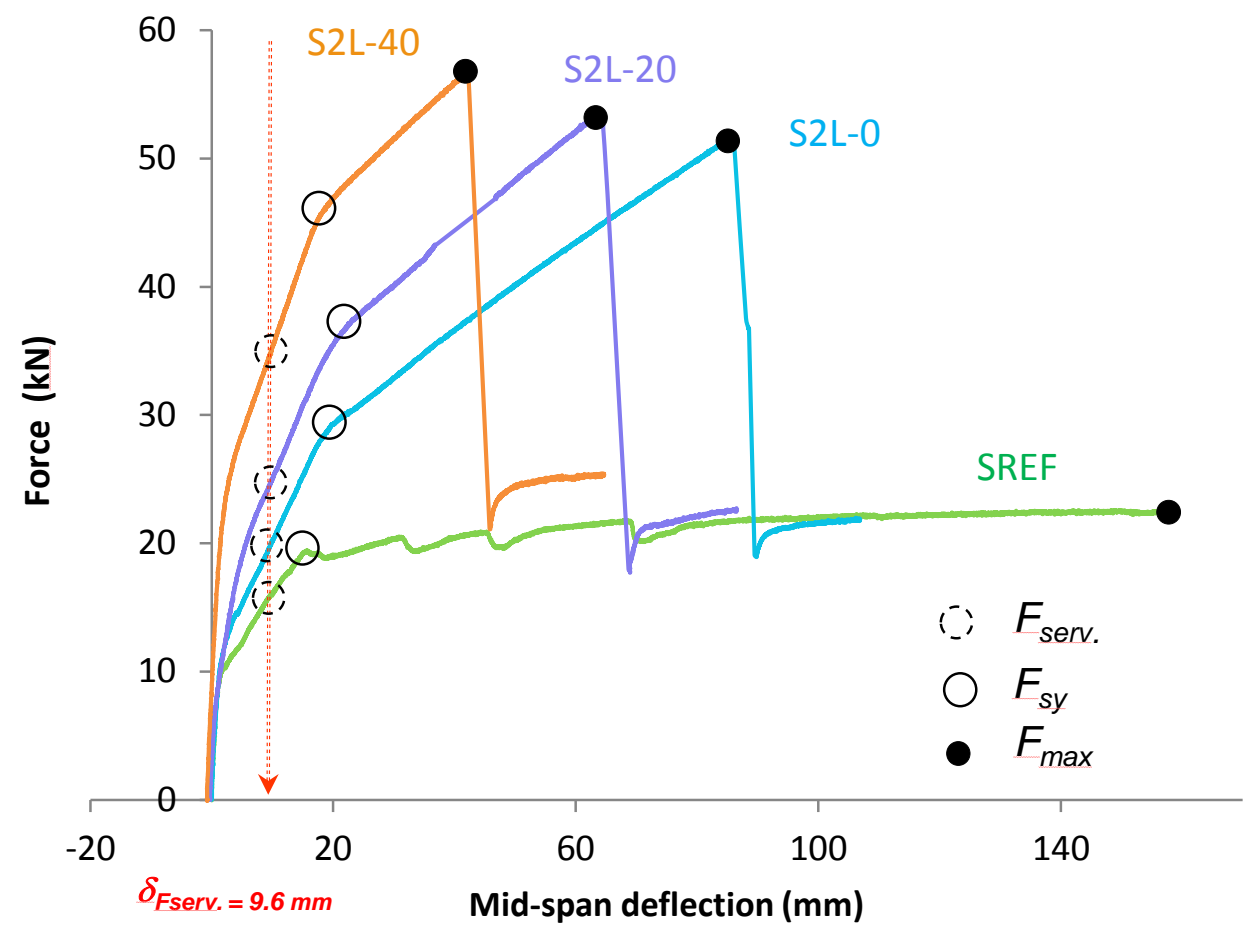

Fig. 7 - Force vs. deflection at mid-span of the tested RC slabs. 


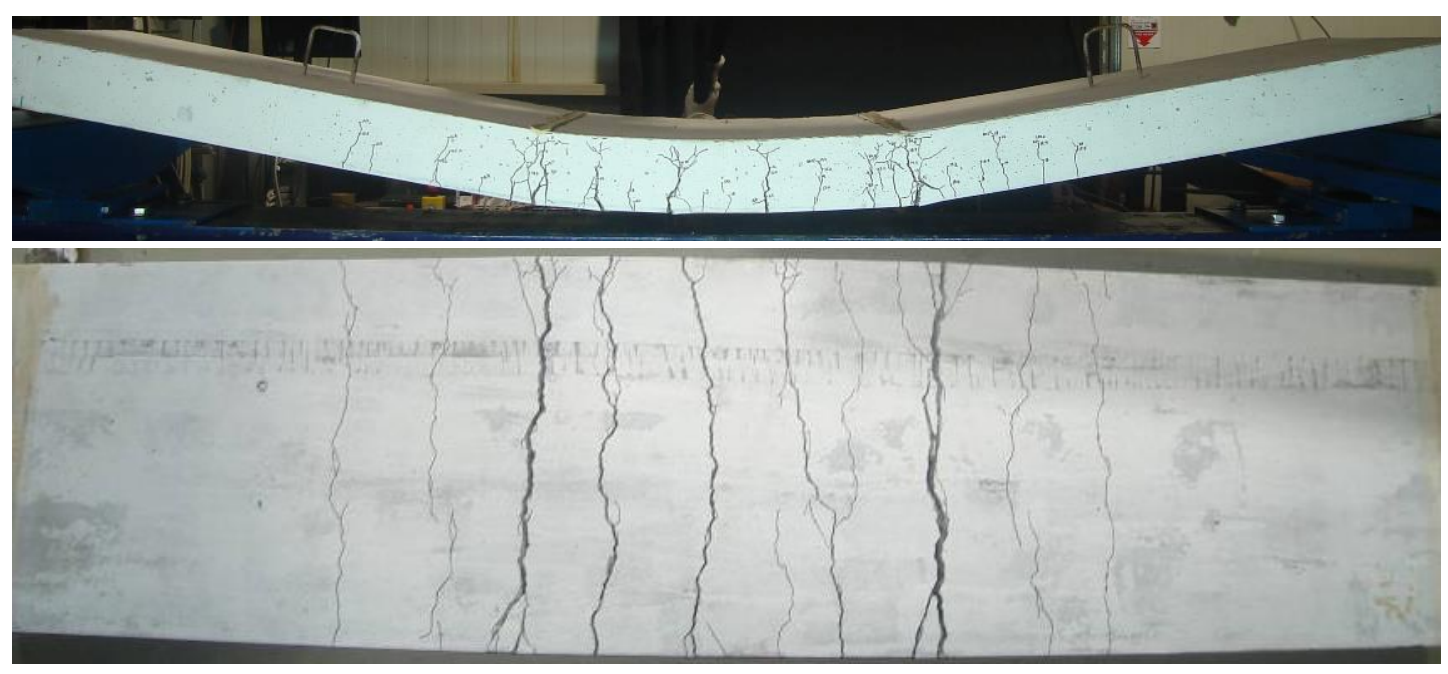

Non-strengthened RC slab (SREF slab)

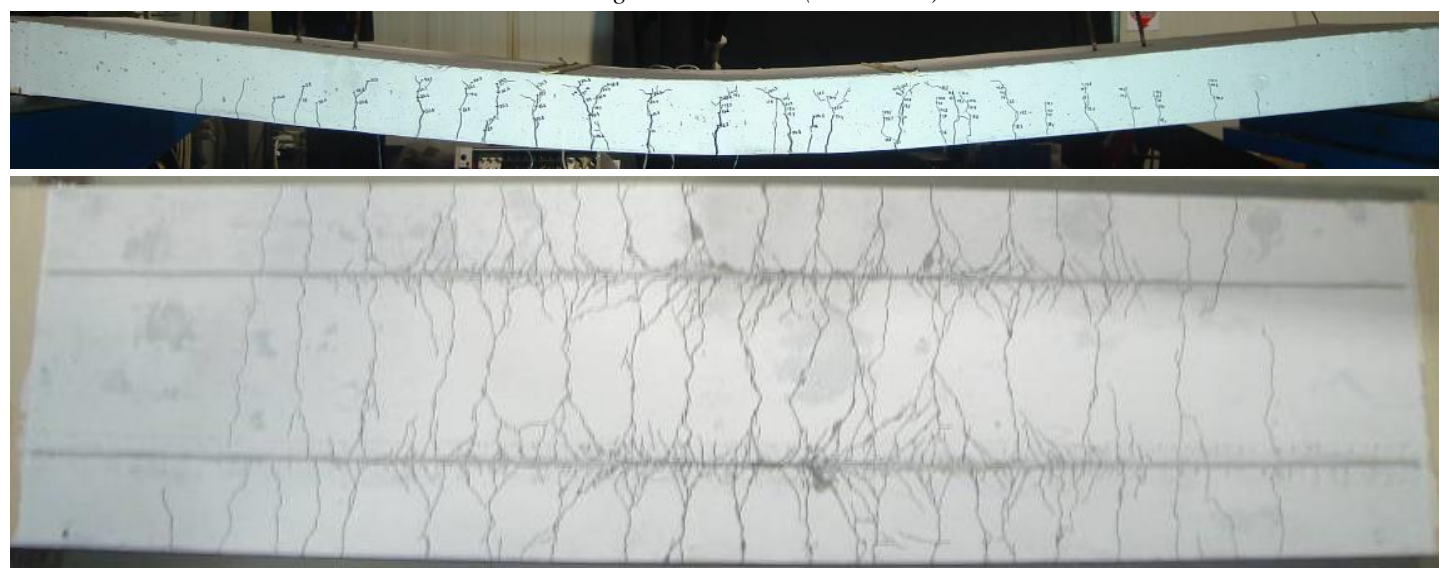

RC slab strengthened with non-prestressed CFRP laminates (S2L-O slab)

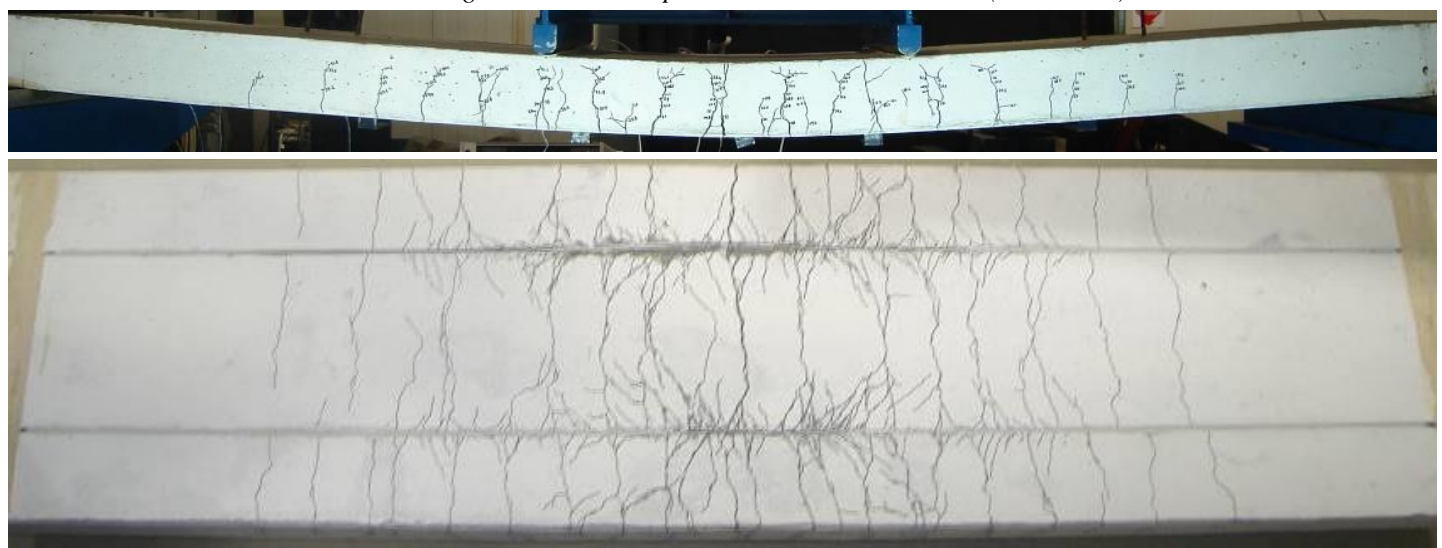

RC slab strengthened with prestressed CFRP laminates - 20\% (S2L-20 slab)

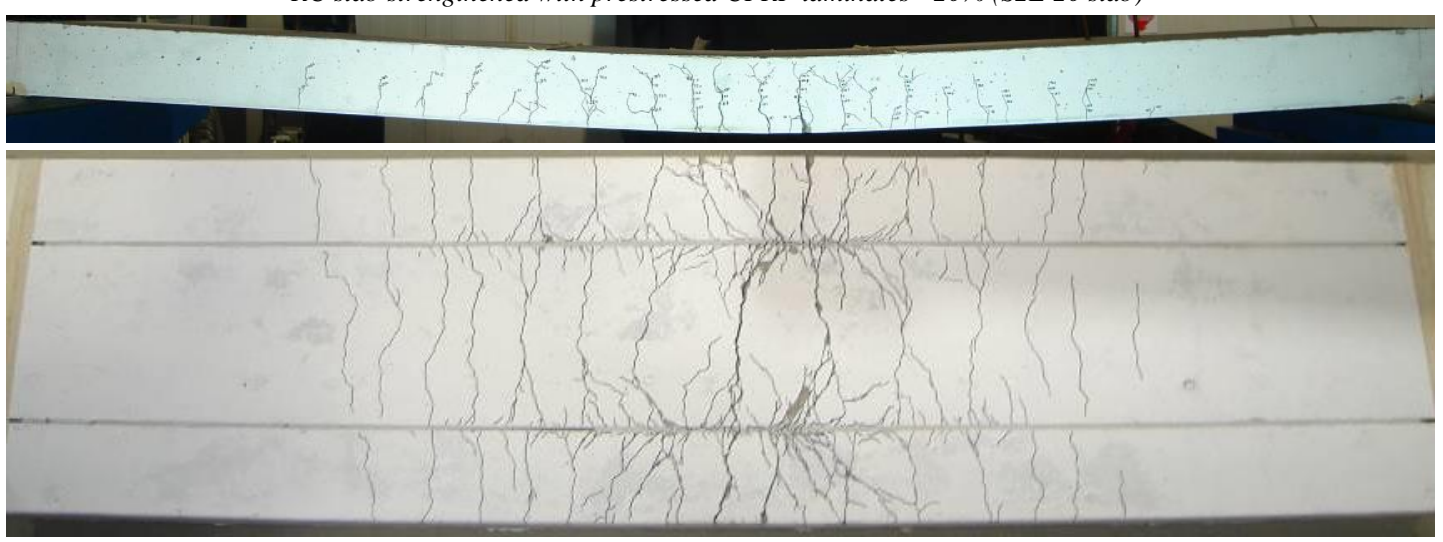

RC slab strengthened with prestressed CFRP laminates - 40\% (S2L-40 slab)

Fig. 8 - Cracking patterns of the tested RC slabs. 

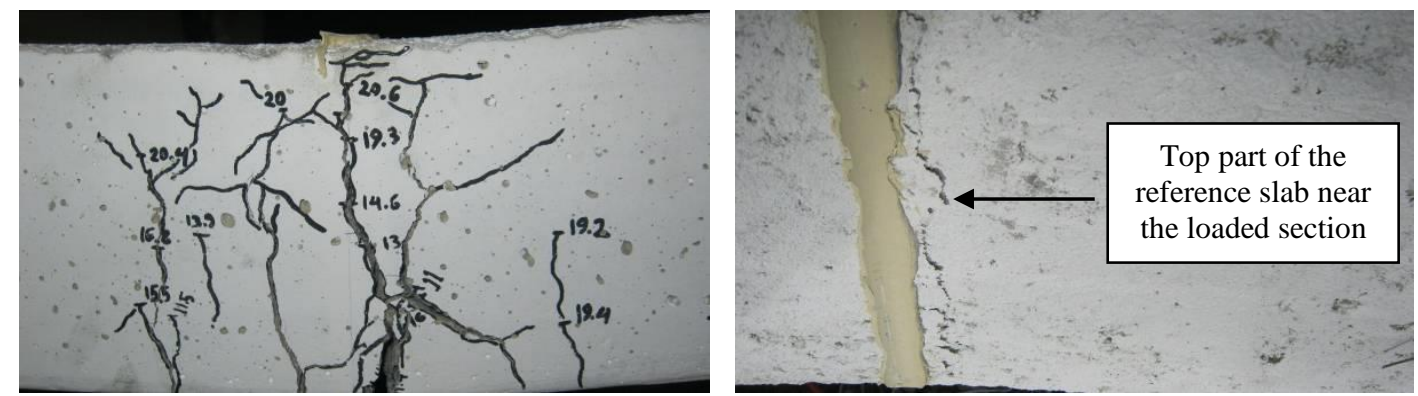

a) Concrete crushing in the reference $R C$ slab
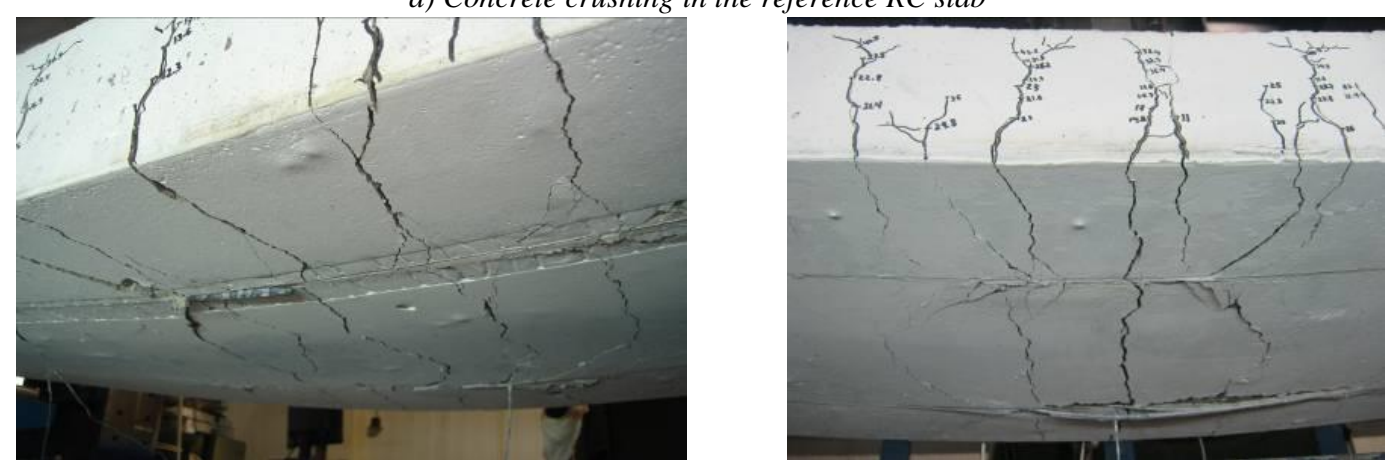

b) Rupture of the CFRP in the slabs strengthened with NSM CFRP laminates

Fig. 9 - Failure modes of the tested RC slabs.

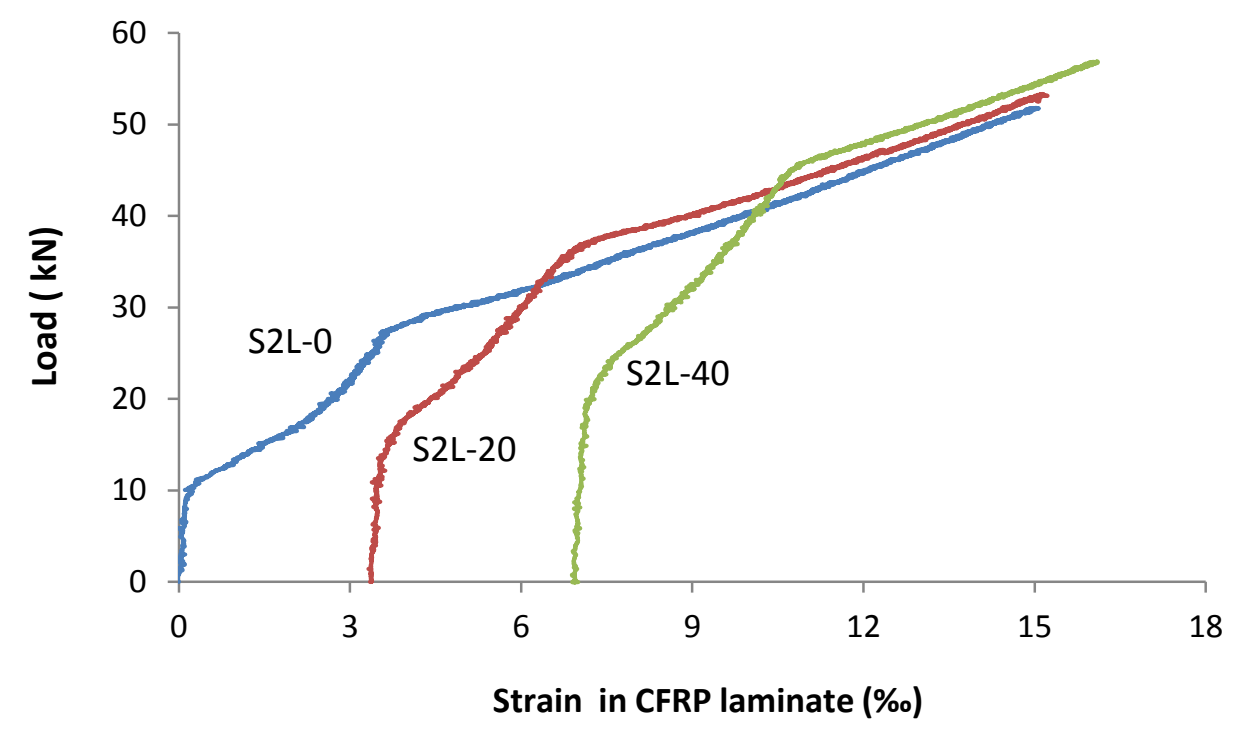

Fig. 10 - Load vs. strain in CFRP laminate (SG-L2, Fig. 4). 


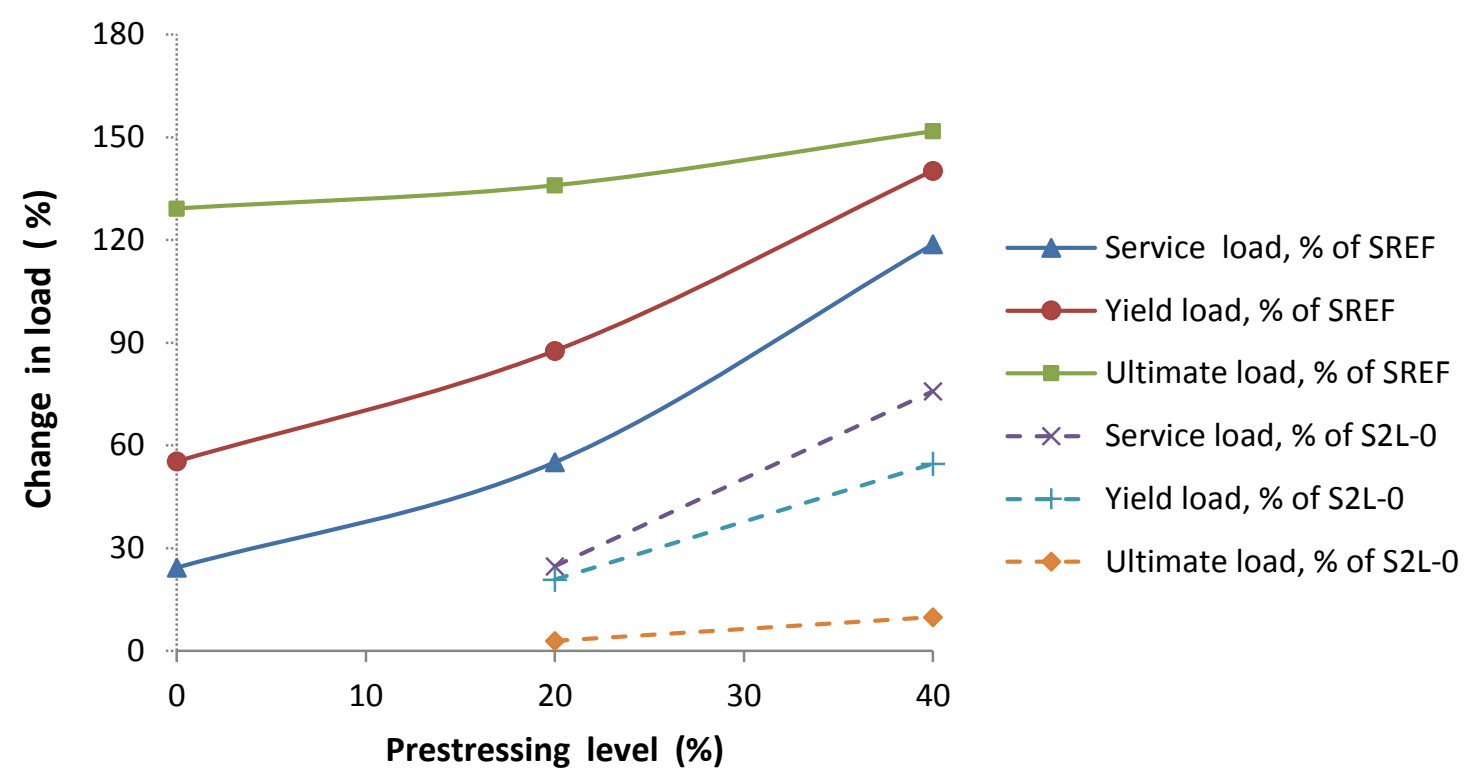

Fig. 11 - Effect of prestressing level on service, yielding and ultimate loads of the RC slabs.

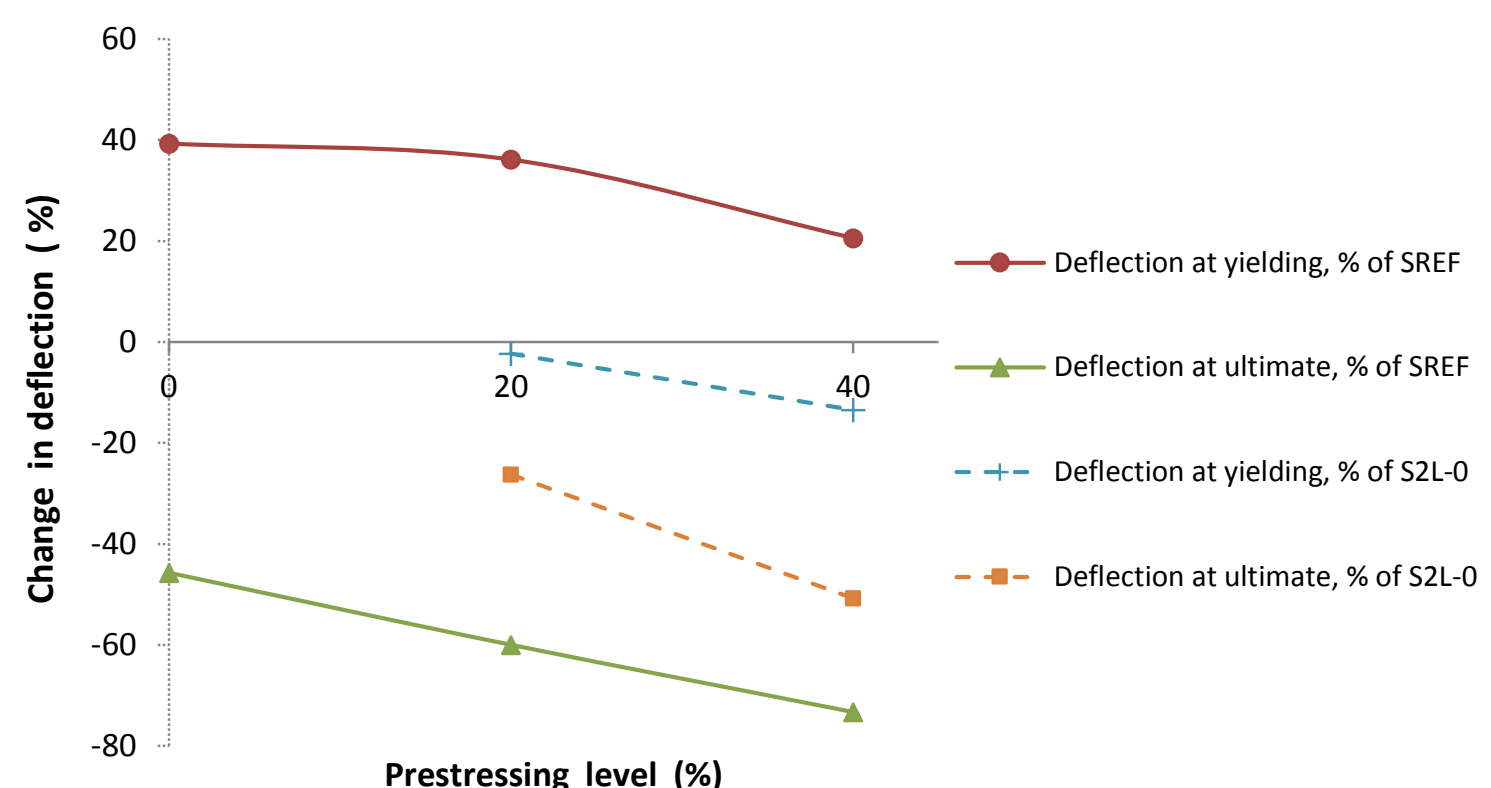

Fig. 12 - Effect of prestressing level on yielding and ultimate deflection of the RC slabs. 


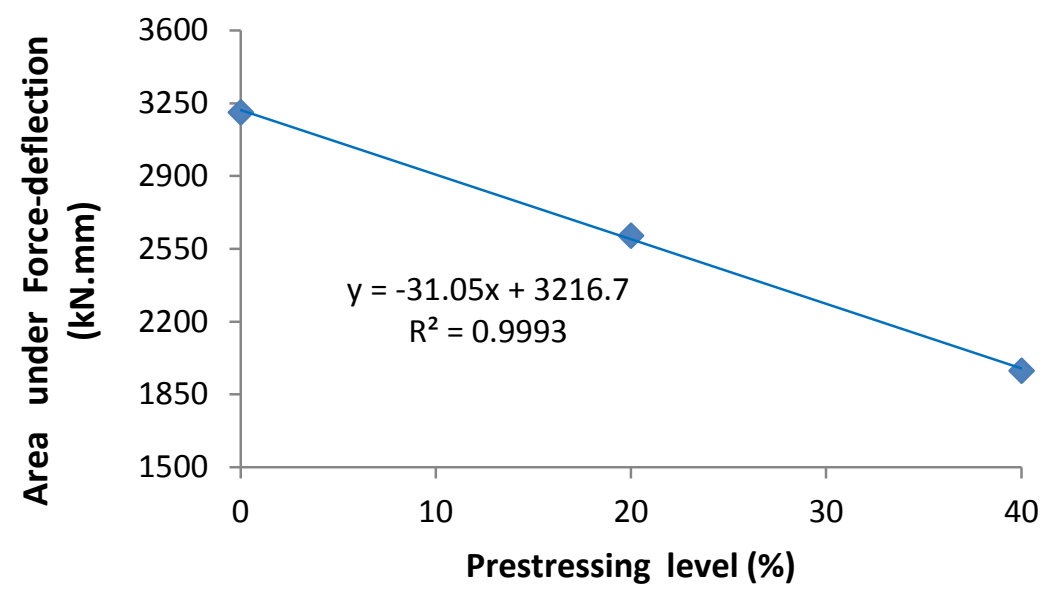

Fig. 13 - Effect of increasing the prestressing level on the ductility of the RC slabs.

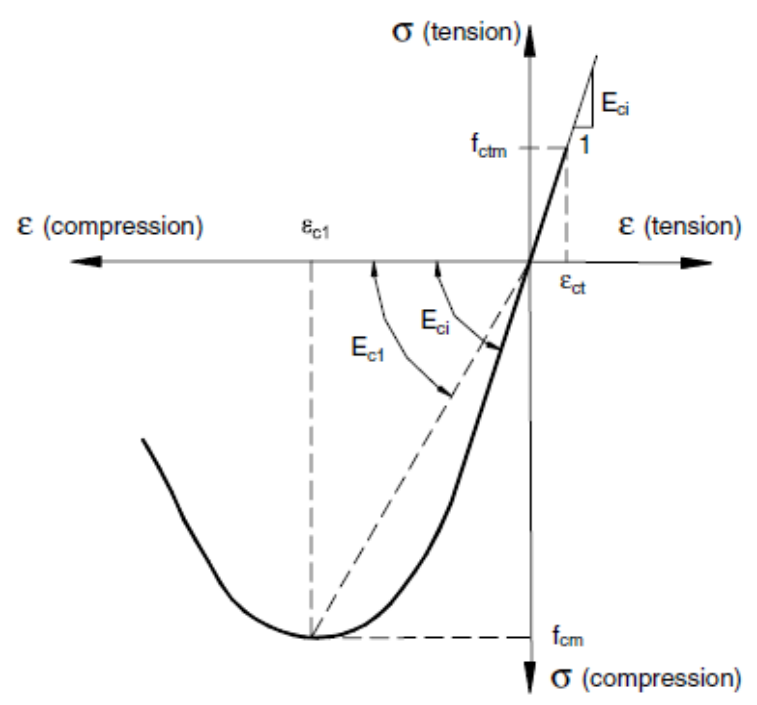

(a)

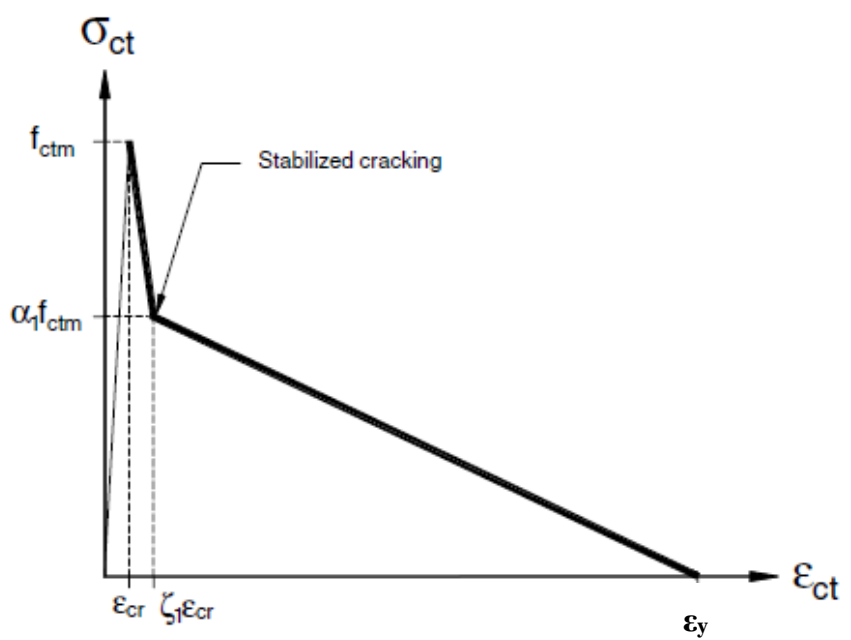

(b)

Fig. 14 - Concrete laws used in the numerical simulation: (a) in compression [23]; (b) in tension [8].

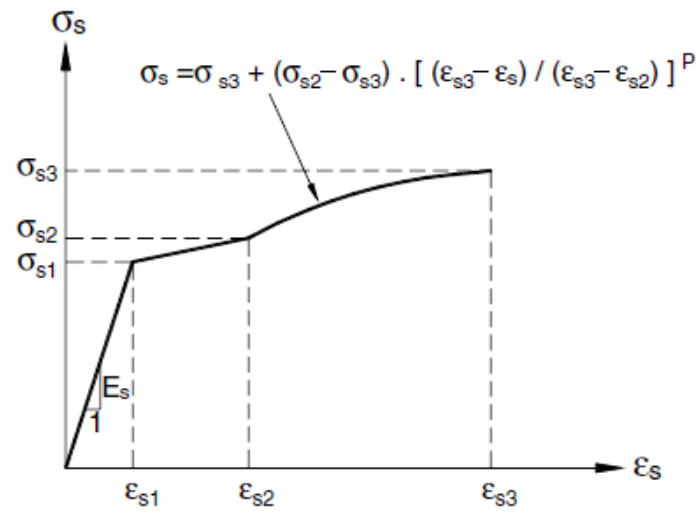

Fig. 15 - Stress-strain relationship for the steel bars [8]. 


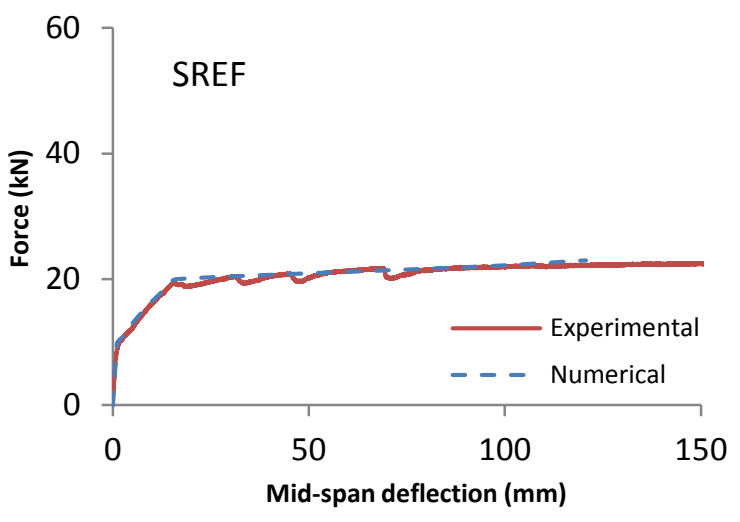

(a)

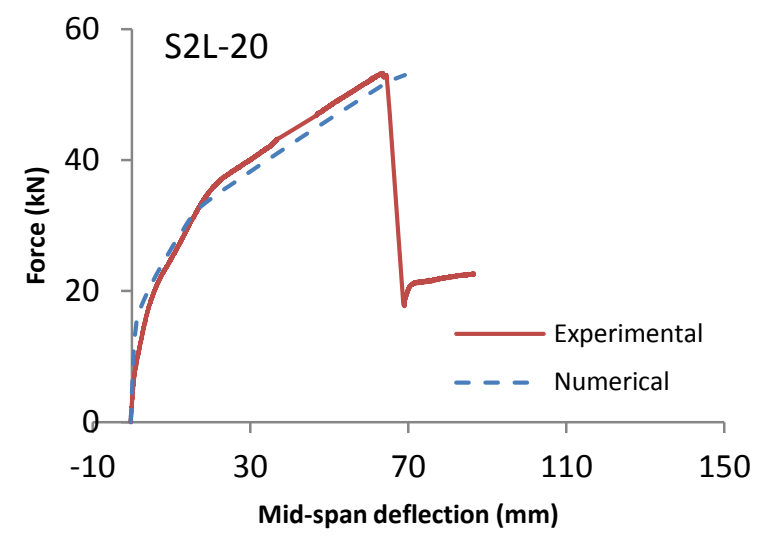

(c)

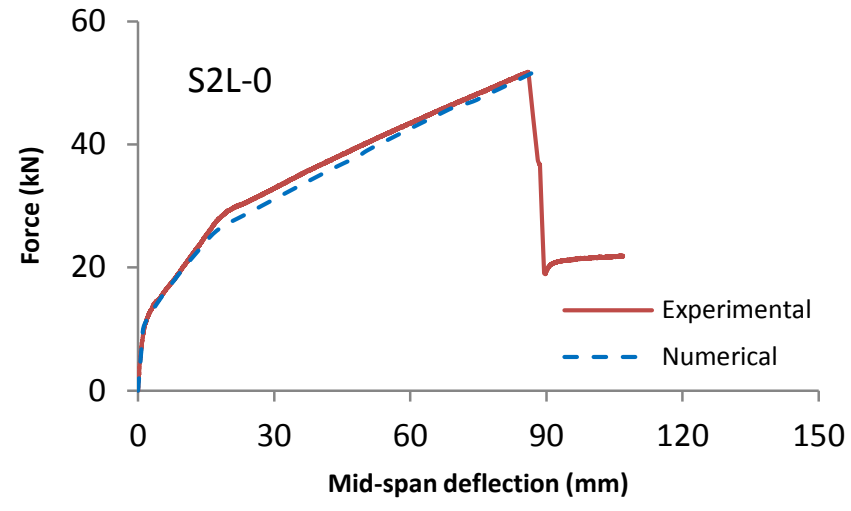

(b)

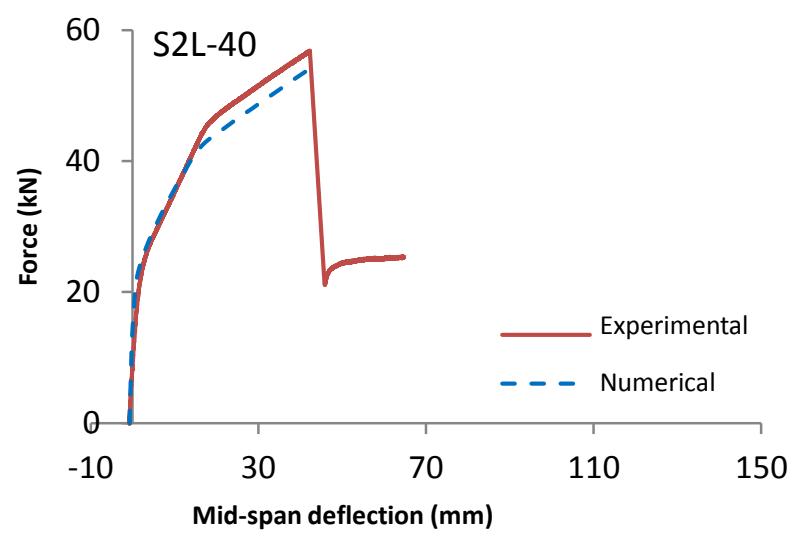

(d)

Fig. 16 - Experimental vs. numerical force-deflection at mid-span for the tested RC slabs: a) SREF, b) S2L-0, c) S2L20, d) S2L-40. 